\title{
Structure of Fish Communities on Outer Slopes of Inshore, Mid-Shelf and Outer Shelf Reefs of the Great Barrier Reef
}

\author{
David McB. Williams and Annamarie I. Hatcher* \\ Australian Institute of Marine Science, P.M.B. No. 3, Townsville, Queensland 4810, Australia
}

\begin{abstract}
The structure of fish communities on the outer reef slopes of one inshore, one mid-shelf and one outer shelf reef in the central region of the Great Barrier Reef was examined using small, quantitative explosive charges. Ten collections, each covering approximately $150 \mathrm{~m}^{2}$ of reef surface, were made on each reef. A total of 323 species belonging to 46 families and comprising 28,537 individuals were collected. Species composition of the communities differed greatly among the 3 reefs. Most species were collected on only 1 or 2 of the 3 reefs. Species richness (number of species per unit area) was greatest on the mid-shelf, lowest inshore and of an intermediate value on the outer shelf reef. The evenness component of species diversity increased across the shelf from inshore to mid-shelf to outer shelf reefs. The biomass of different trophic categories and overall trophic structure differed considerably among the reefs. The most notable differences were the lower biomass of algal grazers on the inshore reef than elsewhere and the considerably greater biomass of planktivores on the mid-shelf reef than elsewhere. Within these major trophic categories and their guilds, there was considerable variation in the distribution of major taxa among the 3 reefs. A number of possible mechanisms causing and maintaining the differences in community structure across the continental shelf are discussed.
\end{abstract}

\section{INTRODUCTION}

The Great Barrier Reef (G.B.R.) comprises approximately 2500 individuals reefs. The geographical range of these reefs is from the Australian mainland to the edge of the continental shelf in an east-west direction and from Latitude $24^{\circ} \mathrm{S}$ to $9^{\circ} \mathrm{S}$, covering nearly $2000 \mathrm{~km}$, in the north-south direction.

In a recent extensive study of the fish communities on reefs in the central region of the G.B.R., Williams (1982) determined that there were major differences in the distribution and relative abundance of species among inshore, mid-shelf and outer shelf reefs.

Here we report on intensive studies of the structure of fish communities on the reef slope of one of the inshore reefs, one of the mid-shelf and one of the outer shelf reefs examined by Williams. The previous study was restricted to visual censuses of a limited number of species. In this study we made relatively complete and quantitative collections of all fish in a given area using

\footnotetext{
- Present address: Department of Zoology, University of
} Western Australia, Nedlands, Western Australia 6009 small, standardised explosive charges (Russell et al., 1978). A general description of the communities, the distribution of species across the shelf, overall patterns of species diversity, the distribution of fish according to their diets and the trophic structure of each community are considered.

\section{MATERIAL AND METHODS}

\section{Study Sites}

The locations of the study sites are illustrated in Fig. 1. Five collections were made at $5 \mathrm{~m}$, and 5 at $9 \mathrm{~m}$ in the areas of outer reef slope with the greatest abundance and diversity of fishes and corals on each of the 3 reefs. These areas are the same as those examined in the previous paper (Fig. 2 in Williams, 1982). Collections were restricted to depths of $9 \mathrm{~m}$ or less due to a combination of the time required to make the collections and decompression limits on the diving collectors. Five $\mathrm{m}$ and $9 \mathrm{~m}$ were chosen to give representative collections within this range. The coral com- 


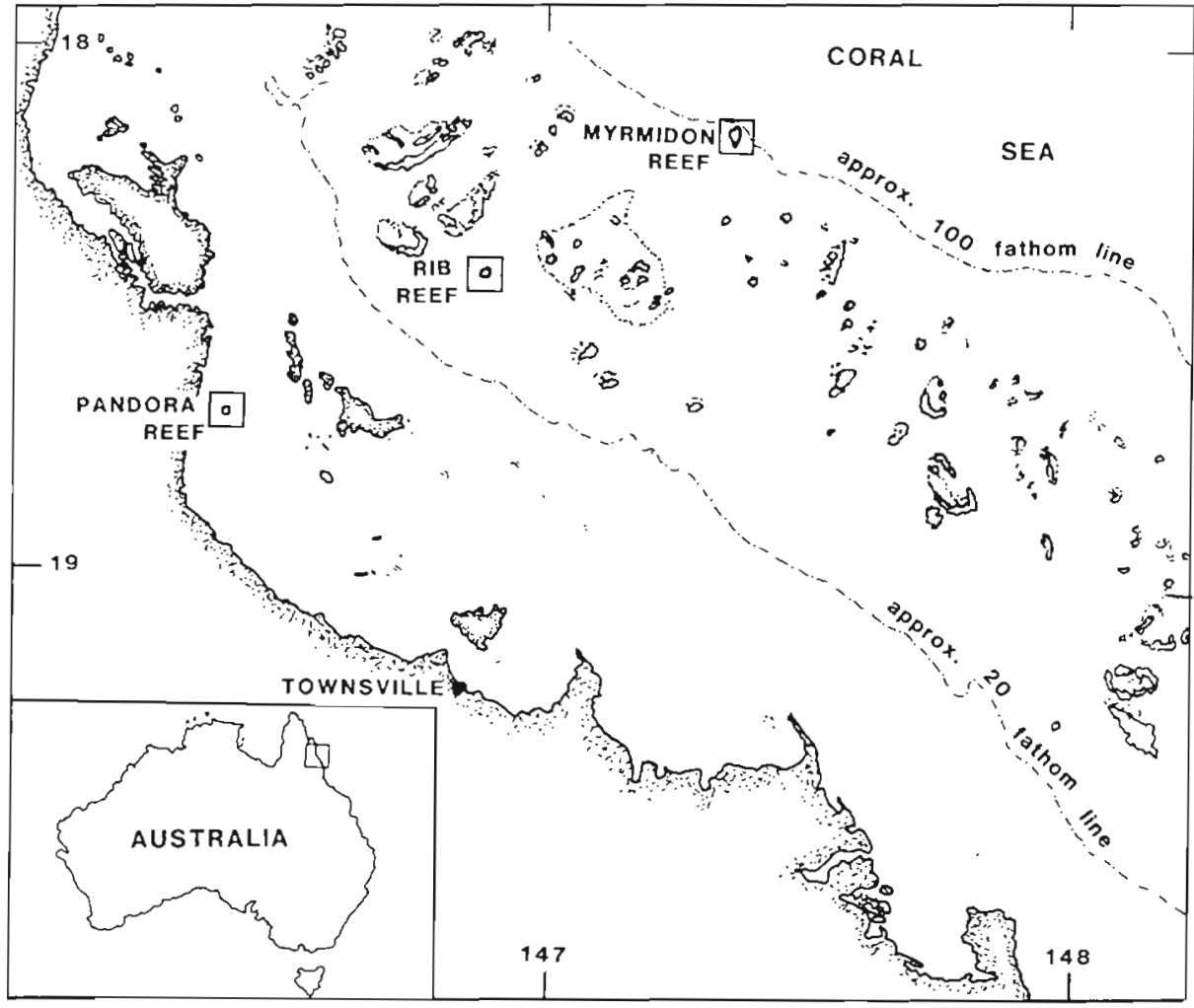

Fig. 1. Geographic locations of Pandora (inshore), Rib (midshelf) and Myrmidon (other shelf) reefs munities associated with the study sites have been characterised by Done (1982) as Acropora palifera' humilis hyacinthus variant and palifera/Porites $(5 \mathrm{~m}$ and $9 \mathrm{~m}$ respectively on outer shelf); Acropora tabulate/branched (both depths, midshelf) and Galaxea (both depths inshore) communities. A general description of the study area and descriptions of the coral communities are given by Done (1982).

\section{Collecting Technique}

Fish were collected using small standardised charges of plastic explosives, as discussed by Russell et al. (1978). The charges were detonated using detonating cord. Immediately after detonation, a team of 6 divers plus 2 people in a boat collected all dead and stunned fish using handnets.

Explosives provide an excellent non-selective method of collecting fish which is highly effective. At the depths used, the charge effectively kilis fish over a radius of about $7 \mathrm{~m}$ or $150 \mathrm{~m}^{2}$ (Russell et al., 1978). Careful attention was taken in laying the charge on the bottom so as not to create 'shadow' areas and the area affected appeared remarkably consistent from one station to the next.

The only serious bias associated with explosive sampling is failure to collect fishes unaffected by the blast. These include species such as eels, many gobiids and trypterygiids and some blennies in which the swim bladder is absent or only poorly developed (Russell et al., 1978).

\section{Trophic Analysis}

Species were assigned to feeding guilds and trophic categories on the basis of literature records, extensive observations in the field and gut content analyses. The guilds chosen and assignments of taxa are similar to those independently arrived at by Harmelin-Vivien (1981), working in the Indian Ocean.

The classification of algal grazers follows Hatcher (1982a). The planktivore guild is self explanatory except for the gelatinous category. All caesionids and no other species were classified within this category. There is considerable overlap between this category and the zooplanktivores except that caesionids generally feed much further from the reef than any other species. One of these species, the deep-bodied Caesio erythrogaster appears to feed primarily on gelatinous plankton such as salps and tunicates. The very streamlined Pterocaesio diagramma and P. tile appear to feed primarily on non-gelatinous zooplankton. $C$. caerulaureus, which is intermediate in body depth between the latter 2 species and the former, also appears intermediate in diet, consuming both gelatinous and non-gelatinous zooplankton (Hamner, Carleton and Jones, unpubl.; own obs.). The invertebrate 
guilds are self explanatory. Confirmed piscivores are those for which fish form the bulk of their diet. Facultative piscivores are those which take fish but for which invertebrates are probably also an important food source.

Comparisons of the trophic impact of small animals relative to larger ones is underestimated if total weights only are compared. One hundred algal grazers totalling 1 kilogram in weight will eat considerably more than one algal grazer weighing $1 \mathrm{~kg}$. To avoid this bias, Goldman (1973) converted biomass figures to estimated metabolic oxygen requirement using the equation of Mann (1965). We also analysed our data using this equation and found that generally the overall results did not differ significantly from those using total weight. Hatcher (1982b) has made relatively direct measurements of the amount of food taken by algal grazers and compared these to the estimates of relative consumption given by comparing total weights and by the Mann equation. He found significant linear correlations between the actual yield to grazers and both the total weight estimation $\left(r^{2}=0.707, \quad P<0.005\right)$ and the estimate based on metabolic oxygen requirement $\left(\mathrm{r}^{2}=0.834, \mathrm{P}<0.001\right)$. Given that we found no major differences in results using either of the 2 estimates and given that the total weight estimate involves fewer assumptions, we chose to present the analyses by total weight. Approximate mean weights of each species are given in parentheses after each species name to give the reader an idea of the relative sizes of species and so that approximate abundances can be determined by back-calculation.

\section{Data Analysis}

The distributions of all trophic groups, guilds and the major taxa among the 3 reefs and 2 depths were examined by 2 factor analyses of variance. No significant interactions occurred between the two factors in any of the analyses.

Cochran's C test was used to test for homogeneity of variances among treatments. The critical probability level for significance of F-ratios and $\mathrm{C}$ values was taken as $1 \%$. All data were transformed to $\log _{10}$ $(x+1)$ since this transform considerably stabilised the variances. Means were ranked using the StudentNewman-Keuls procedure (Underwood, 1981).

Despite transformation of the data, variances of 10 of the 42 cases analysed remained heterogeneous although generally only slightly so. Box (1953) has indicated that the analysis of variance is, however, robust to many types of magnitudes of departure from homogeneity of variances, particularly where sample sizes are equal, as in the present study. Examination of the raw data indicated that a major cause of significant heterogeneity was the frequent total absence of the fish under consideration at one end of the transect - the inshore or outer shelf reefs. In this situation, means and variances of 2 (1 reef, shallow and deep) of the 6 treatments are zero. Analyses were carried out in these cases if the calculated $C$ value did not exceed the tabled critical value for four treatments.

\section{RESULTS}

\section{General Description}

A total of 323 species belonging to 45 families and comprising 28,537 individuals were collected. The majority (208) of species were rare $(<10$ individuals in the total collection) and the average size of individuals was small, with a mean overall weight of only $26 \mathrm{~g}$.

Significantly fewer individuals per station were collected on the outer shelf than elsewhere and mean total weight of the $5 \mathrm{~m}$ collections was higher than that of the $9 \mathrm{~m}$ collections (Table 1 ). The mean total weight of the mid-shelf collections was significantly higher than that from inshore stations but the total weight of the outer shelf collections was not significantly different from either of the others. Thus in broad terms (relative to the mid-shelf) there are numerous small fish inshore and fewer, larger fish offshore. The size

Table 1. Mean number of species and individuals, mean total weight and mean values of the Shannon-Wiener index of diversity $\left(\mathrm{H}^{\prime}\right.$, based on $\left.\log _{e}\right)$ and Pielou's evenness index $\left(\mathrm{J}^{\prime}=\mathrm{H}^{\prime} / \log _{e} \mathrm{~S}\right)$ at each station at each reef. F F-ratios for contributions of reefs and depths, respectively, to analysis of variance; SNK Student-Newmann-Keuls test for ranking of means; O outer shelf; $M$ mid-shelf; I inshore. ns $\mathrm{P}>0.01 ; \cdots \mathrm{P}<0.01 ; \cdots \mathrm{P}<0.001 ;$ ' for all significant depth differences, total weight greater at $5 \mathrm{~m}$ than $9 \mathrm{~m}$

\begin{tabular}{|c|c|c|c|c|c|c|}
\hline \multirow[t]{2}{*}{ Parameter } & \multirow[t]{2}{*}{ Inshore } & \multirow[t]{2}{*}{ Mid-shelf } & \multirow[t]{2}{*}{ Outer shelf } & \multicolumn{2}{|c|}{ Reefs } & \multirow{2}{*}{$\begin{array}{c}\text { Depth } \\
F^{\prime}\end{array}$} \\
\hline & & & & $\mathrm{F}$ & SNK & \\
\hline No. individuals & 1097 & 1273 & 483 & $\cdots$ & $M=I>0$ & ns \\
\hline Total weight $(\mathrm{kg})$ & 13.8 & 35.6 & 23.4 & $\cdot \cdot$ & ambiguous & $\cdots$ \\
\hline No. species & 38 & 70 & 56 & $\cdots$ & $\mathrm{M}>\mathrm{O}>\mathrm{I}$ & ns \\
\hline $\mathrm{H}^{\prime}$ & 1.56 & 2.38 & 2.98 & $\cdots$ & $O>M>I$ & ns \\
\hline$J^{\prime}$ & 0.431 & 0.562 & 0.748 & $\cdots$ & $\mathrm{O}>\mathrm{M}>\mathrm{I}$ & ns \\
\hline
\end{tabular}




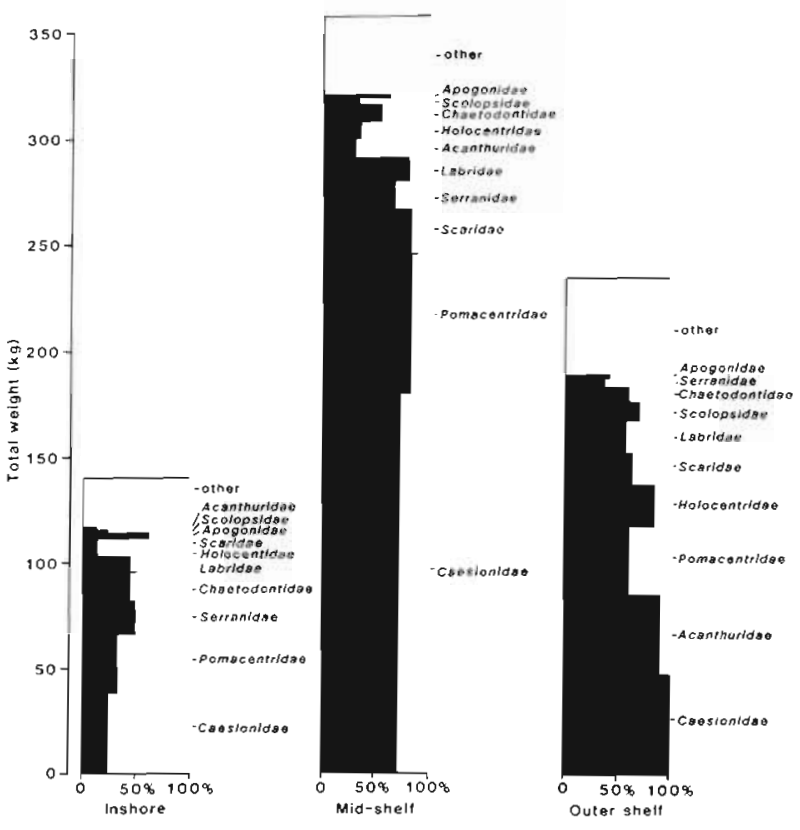

Fig. 2. Total weight of the 10 major families collected on each reef (pooled over all depths and stations). The horizontal breakdown indicates the proportion of the total number of species (of a family) collected that were collected on a given reef

differences are generally a reflection of smaller species inshore and larger ones offshore, rather than of intraspecific weight differences among reefs.

Ten families accounted for over $75 \%$ of the weight of the total collection on all reefs (Fig. 2). The caesionids were the largest contributor to total weight on all 3 reefs. The family Pomacentridae was the second most important contributor to total weight on both inshore and mid-shelf reefs and the third on the outer shelf (the second being the Acanthuridae).

The same 10 families accounted for $97 \%$ of all individuals collected. The pomacentrids accounted for $76 \%$ of individuals over all reefs and the caesionids $11 \%$. Pomacentrids comprised 77,82 and 54 percent of individuals on the inshore, mid-shelf and outer shelfs reefs, respectively.

\section{Species Distributions}

Species composition of the communities differed greatly among reefs (Fig. 3): $60 \%$ of all species were collected at only 1 of the 3 reefs and only $7 \%$ were cosmopolitan. Of the 128 species occurring on more than one reef, 82 occurred in sufficient numbers to compare their abundances between the 2 or 3 reefs on which they occurred (Chi-square comparison to an even distribution where expected values were $>5$ ). The abundances of 54 of these species $(66 \%)$ differed
A

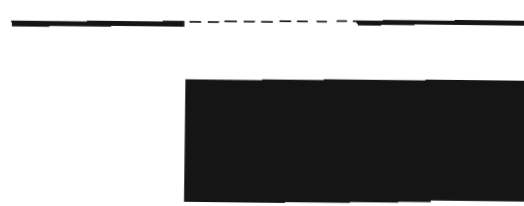

$(n=1)$

B

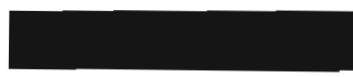

$(n=37)$

D

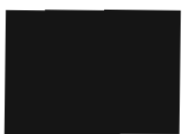

$(n=69)$

D

E

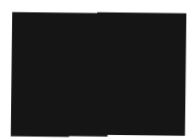

$(n=71)$

$\mathrm{F}$

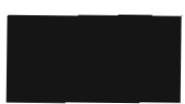

$(n=50)$

G

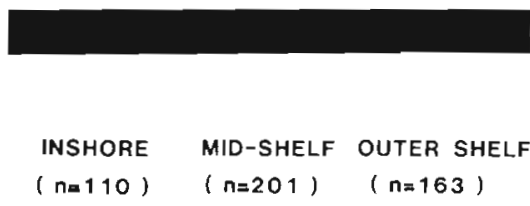

$(n=22)$

Fig. 3. Distribution of species across the 3 reefs. The height of each bar is proportional to the number of species with that distribution; $n$ number of species associated with each row or column. A species collected inshore and outer shelf; B species collected mid-shelf and outer shelf; $C$ species collected inshore and mid-shelf; D, E, and F species collected only outer shelf, only mid-shelf and only inshore, respectively; $G$ cosmopolitan species collected in all 3 areas

significantly among the reefs on which the species did occur (for 48 spp. $\mathrm{P}<0.01$; for $6 \mathrm{spp} .0 .05>\mathrm{P}>0.01$ ). The distribution of only 2 of the cosmopolitan species, Epibulus insidiator (a labrid) and Apogon coccineus (an apogonid), did not differ significantly $(\mathrm{P}>0.05)$ from an even distribution across the 3 reefs.

\section{Species Diversity}

The mean number of species per station was greatest on the mid-shelf, lowest inshore and of an intermediate value on the outer shelf reef (Table 1). The ShannonWiener index of species diversity, $\mathrm{H}^{\prime}$, increased markedly with distance from the mainland (Table 1). This pattern is due to an increase in the evenness component of species diversity estimated by $\mathrm{J}$ ' in Table 1. 


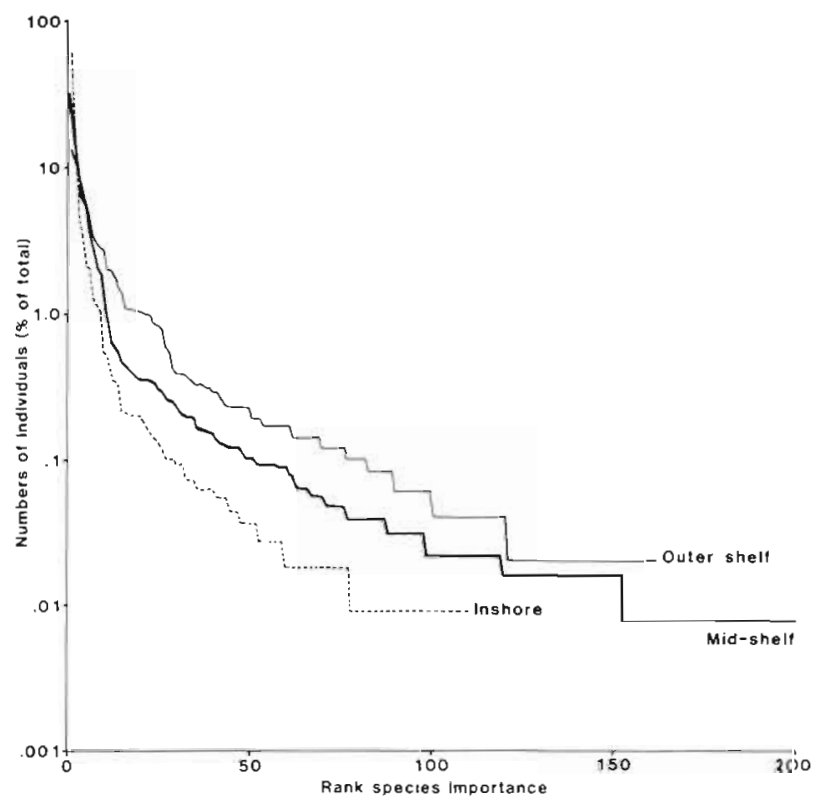

Fig. 4. Dominance-diversity curves for total collections on inshore, mid-shelf and outer shelf reefs

rather than the species richness component (Peet, 1974). The change in evenness is clearly demonstrated by the dominance-diversity curves (Whittaker, 1969) for each reef (Fig. 4). The further the community is from the mainland, the more evenly the numbers of individuals are divided among the species present. Three families, the Chaetodontidae, Holocentridae and Acanthuridae demonstrated an apparent increase in the number of species from inshore to the outer shelf (Table 2). Other families demonstrated maximum species richness inshore or on the mid-shelf.

\section{Distribution of Trophic Groups}

Each species was assigned to one of 14 guilds (sensu Root, 1967, see Methods). These 14 categories were further lumped into 4 broader trophic categories: algal grazers, planktivores, piscivores and invertebrate (non-planktonic) feeders. Among these 4 categories, planktivores comprised the majority of individuals $(85 \%)$ and were the largest contributor to the total weight $(57 \%)$ but the other invertebrate feeders comprised the largest number of species (57\%) (Table 3 ). The total weight of these 4 trophic groups varied considerably among the reefs (Table 4 ). We now examine these differences between reefs in more detail.

\section{Algal Grazers}

The mean total weight of algal grazers increased with distance from the mainland but the SNK compari-
Table 2. Total number of species collected in 10 explosive stations at each reef for 9 most diverse families

\begin{tabular}{|lrrrr|}
\hline \multicolumn{1}{|c}{ Family } & Inshore & $\begin{array}{c}\text { Mid- } \\
\text { shelf }\end{array}$ & $\begin{array}{c}\text { Outer } \\
\text { shelf }\end{array}$ & Total \\
\hline Pomacentridae & 17 & 43 & 30 & 57 \\
Labridae & 17 & 29 & 27 & 46 \\
Chaetodontidae & 9 & 15 & 20 & 28 \\
Gobijdae & 11 & 11 & 0 & 21 \\
Serranidae & 11 & 14 & 7 & 22 \\
Apogonidae & 11 & 10 & 5 & 17 \\
Holocentridae & 2 & 6 & 13 & 16 \\
Scaridae & 3 & 11 & 9 & 14 \\
Acanthuridae & 1 & 3 & 9 & 10 \\
Miscellaneous & 28 & 59 & 43 & 92 \\
Total & 110 & 201 & 163 & 323 \\
\hline
\end{tabular}

Table 3. Total numbers of species, individuals and weight of fish collected, pooled over all reefs and depths

\begin{tabular}{|crrr|}
\hline $\begin{array}{c}\text { Trophic categories } \\
\text { Guilds }\end{array}$ & Species & $\begin{array}{c}\text { Indi- } \\
\text { viduals }\end{array}$ & $\begin{array}{c}\text { Weight } \\
(\mathrm{kg})\end{array}$ \\
\hline Algal grazers & 48 & 1884 & 119.1 \\
Suckers & 3 & 189 & 32.0 \\
Small croppers & 21 & 1427 & 33.1 \\
Large croppers & 11 & 104 & 17.7 \\
Scrapers & 13 & 164 & 36.3 \\
Planktivores & 64 & 24352 & 416.2 \\
Zooplankton & 38 & 8947 & 72.0 \\
Omnivorous & 21 & 11967 & 58.1 \\
Gelatinous & 4 & 3193 & 266.5 \\
Algal & 1 & 245 & 19.6 \\
Invertebrate feeders & 185 & 2003 & 151.4 \\
Motile & 146 & 1241 & 108.1 \\
Sessile & 10 & 87 & 10.3 \\
Sessile omnivores & 14 & 69 & 11.0 \\
Coral feeders & 15 & 606 & 22.0 \\
Piscivores & 26 & 298 & 42.0 \\
Confirmed & 11 & 45 & 16.2 \\
Facultative & 15 & 253 & 25.8 \\
Total & 323 & 28537 & 728.9 \\
& & & \\
\hline
\end{tabular}

son indicates only that the total weight of algal grazers was significantly lower inshore than elsewhere (Table 4). One of the guilds, the suckers (primarily Ctenochaetus striatus, mean weight of $140 \mathrm{~g} \mathrm{fish}^{-1}$ ), did increase significantly in mean total weight with distance from the mainland. The total weight of scrapers (family Scaridae) was significantly greater on the midand outer shelf than inshore but that of large croppers did not vary significantly among reefs. Results of the analysis of small croppers are ambiguous, with a significantly greater total weight on the outer shelf than inshore but with that on the mid-shelf not differing significantly from either the outer shelf or inshore. 
Table 4. Total weight of each trophic category and guild collected on each reef and proportional contribution of each group to total weight at each reef (in parentheses). Symbols as in Table 1. T heterogeneity of variances prevents analysis. for all significant depth differences, total weight greater at $5 \mathrm{~m}$ than $9 \mathrm{~m}$

\begin{tabular}{|c|c|c|c|c|c|c|c|c|c|}
\hline \multirow{2}{*}{$\begin{array}{l}\text { Trophic categories } \\
\text { Guilds }\end{array}$} & \multicolumn{2}{|c|}{ Inshore } & \multicolumn{2}{|c|}{ Mid-Shelf } & \multicolumn{2}{|c|}{ Outer Shelf } & \multicolumn{2}{|r|}{ Reefs } & \multirow{2}{*}{$\begin{array}{l}\text { Depth } \\
\text { F }^{\prime}\end{array}$} \\
\hline & WT. (kg) & $(\%)$ & WT. (kg) & $(\%)$ & WT. $(\mathrm{kg})$ & $(\%)$ & $\mathrm{F}$ & SNK & \\
\hline Algal grazers & 12.8 & $(9.3)$ & 38.8 & $(10.8)$ & 68.0 & (29.1) & $\cdots$ & $O=M>I$ & $\cdots$ \\
\hline Suckers & 0 & & 4.6 & $(1.3)$ & 27.4 & (11.7) & $\cdots$ & $O>M>I$ & $\cdots$ \\
\hline Small croppers & 6.4 & $(4.6)$ & 10.0 & $(2.8)$ & 18.0 & $(7.7)$ & $\cdots$ & ambiguous & ns \\
\hline Large croppers & 3.7 & $(2.7)$ & 4.7 & (1.6) & 8.1 & (3.5) & ns & - & $\cdots$ \\
\hline Scrapers & 2.7 & $(2.0)$ & 19.5 & $(5.5)$ & 14.5 & (6.2) & $\cdots$ & $\mathrm{O}=\mathrm{M}>\mathrm{I}$ & ns \\
\hline Planktivores & 62.7 & $(45.4)$ & 252.6 & $(70.9)$ & 100.9 & $(43.0)$ & $\cdots$ & $\mathrm{M}>\mathrm{O}=\mathrm{I}$ & ns \\
\hline Zooplankton & 3.8 & $(2.8)$ & 42.3 & $(11.9)$ & 25.9 & $(11.0)$ & $\cdots$ & $M=O>I$ & ns \\
\hline Omnivorous & 21.3 & $(15.4)$ & 29.9 & $(8,4)$ & 6.9 & $(2.9)$ & $\cdots$ & $M=I>0$ & ns \\
\hline Gelatinous & 37.6 & $(27.2)$ & 180.4 & $(50.7)$ & 48.5 & $(20.7)$ & ns & - & ns \\
\hline Algal & 0 & & 0 & & 19.6 & $(8.4)$ & $\Psi$ & - & - \\
\hline Invertebrate feeders & 47.1 & $(34.1)$ & 43.5 & $(12.2)$ & 60.7 & $(25.9)$ & ns & - & ns \\
\hline Motile & 29.0 & $(21.0)$ & 28.8 & $(8.1)$ & 50.2 & $(21.4)$ & ns & - & ns \\
\hline Sessile & 5.4 & (3.9) & 1.5 & (0.4) & 3.4 & (1.4) & ns & - & ns \\
\hline Sessile omnivores & 5.0 & (3.6) & 4.3 & $(1.2)$ & 1.7 & $(0.7)$ & ns & - & ns \\
\hline Coral & 7.7 & $(5.6)$ & 8.9 & (2.5) & 5.4 & (2.3) & ns & - & ns \\
\hline Piscivores & 15.5 & $(11.2)$ & 21.1 & $(6.1)$ & 4.7 & $(2.0)$ & $\cdots$ & $\mathrm{I}=\mathrm{M}>\mathrm{O}$ & ns \\
\hline Confirmed & 2.7 & $(2.0)$ & 9.8 & $(2.9)$ & 3.0 & $(1.3)$ & $\mathrm{ns}$ & - & ns \\
\hline Facultative & 12.8 & (9.3) & 11.3 & $(3.2)$ & 1.7 & $(0.7)$ & $\cdots$ & $I=M>O$ & ns \\
\hline Total & 138.1 & & 356.0 & & 234.3 & & & & \\
\hline
\end{tabular}

Among the small and large croppers there was a range of distributions across the shelf (Table 5). Five of the 9 taxa were present in significantly greater total weight on the outer shelf than elsewhere: Plectroglyphidodon spp. (P. dickii, $16 \mathrm{~g}$; P. lacrymatus, $26 \mathrm{~g}$ ), Pomacentrus bankanensis (11 g), Stegastes fasciolatus (30 g), Centropyge spp. (18 g) and the larger Acanthuridae (>150 g). Two taxa, Paraglyphidodon spp. P. melas, (85) g; P. behni, (20) $\mathrm{g}$ - and the Siganidae $(120 \mathrm{~g})$ had a greater biomass inshore and on the midshelf than on the outer shelf. The total weight of Pomacentrus wardi $(12 \mathrm{~g})$ decreased with distance from the mainland and that of Zebrasoma scopas $(120 \mathrm{~g})$ was greatest on the mid shelf.

The algal grazers were the only trophic category and the suckers and large croppers the only guilds, to differ significantly in biomass among the different depths sampled. Each of these groups had a significantly higher biomass at the shallower sites than the deeper. Among the small croppers, Stegastes fasciolatus and Pomacentrus bankanensis also were more abundant at $5 \mathrm{~m}$ than $9 \mathrm{~m}$

The relative importance of the guilds differed greatly among the reefs. Inshore, the small croppers (all pomacentrids) and the large croppers (primarily siganids) comprised $50 \%$ and $29 \%$ respectively of all algal grazers. The scrapers were clearly the most important group on the mid-shelf $(50 \%$ of the total) followed by the small croppers $(26 \%)$. On the outershelf, the suckers were dominant $(39 \%)$, followed by the small croppers (26\%) and scrapers (23\%).

\section{Planktivores}

The total weight of planktivores was considerably greater on the midshelf than inshore or on the outer shelf (Table 4). Zooplanktivores were most abundant on the mid-shelf and outer shelf and omnivorous planktivores on the mid-shelf and inshore. No significant variation in the total weight of gelatinous planktivores across the shelf was detected, due at least in part to huge variances among collections within reefs. The fourth guild, the algal planktivores, was represented by a single large school of garfish Hemiramphus dussumieri, and it is unlikely that the collection accurately represents the distribution of this group.

As observed for the algal grazers, the patterns demonstrated by the guilds of planktivores are the sum of a number of different patterns among the component taxa. For example, the large biomass of zooplanktivores on the mid-shelf is solely due to the presence of 2 very abundant species, Chromis atripectoralis (5 g) and Neopomacentrus azysron ( $3 \mathrm{~g})$. Other zooplanktivorous taxa increased in abundance with increasing distance from shore (other Chromis spp.) or did not 
Table 5. Distribution of major taxa of small croppers and large croppers (algal grazing guilds), expressed as total weight (kg) in all collections, across inshore, mid-shelf and outer shelf reefs. Symbols as in Table 1. ' for all significant depth differences, total weight greater at $5 \mathrm{~m}$ than $9 \mathrm{~m}$

\begin{tabular}{|c|c|c|c|c|c|c|c|}
\hline \multirow[t]{2}{*}{ Guild } & \multirow[t]{2}{*}{ Taxon } & \multirow[t]{2}{*}{ Inshore } & \multirow[t]{2}{*}{ Mid-shelf } & \multirow[t]{2}{*}{ Outer shelf } & \multicolumn{2}{|r|}{ Reefs } & \multirow{2}{*}{$\begin{array}{c}\text { Depth } \\
F^{\prime}\end{array}$} \\
\hline & & & & & $\mathrm{F}$ & SNK & \\
\hline \multicolumn{8}{|c|}{ Small croppers } \\
\hline & Pomacentridae (Total) & $(6.4)$ & $(5.6)$ & (13.1) & & & \\
\hline & Paraglyphidodon spp. & 3.1 & 2.1 & $0.0^{\prime}$ & $\cdots$ & $I=M>0$ & ns \\
\hline & Plectroglyphidodon spp. & 0.0 & 1.8 & 7.0 & $\cdots$ & $O>M>I$ & ns \\
\hline & Pomacentrus bankanensis & 0.0 & 0.1 & 1.1 & $\cdots$ & $\mathrm{O}>\mathrm{M}=\mathrm{I}$ & $\cdots$ \\
\hline & Pomacentrus wardi & 2.7 & 0.8 & 0.0 & $\cdots$ & $\mathrm{I}>\mathrm{M}>\mathrm{O}$ & ns \\
\hline & $\begin{array}{l}\text { Stegastes fasciolatus } \\
\text { Acanthuridae }\end{array}$ & 0.1 & 0.3 & 4.6 & $\cdots$ & $O>M=I$ & $\cdots$ \\
\hline & $\begin{array}{c}\text { Zebrasoma scopas } \\
\text { Pomacanthidae }\end{array}$ & 0.0 & 2.7 & 1.0 & $\cdots$ & $\mathrm{M}>\mathrm{O}=\mathrm{I}$ & ns \\
\hline & Centropyge spp. & 0.0 & 1.2 & 2.7 & $\cdots$ & $O>M>I$ & ns \\
\hline & Miscellaneous & 0.0 & 0.5 & 1.2 & & & \\
\hline \multicolumn{8}{|c|}{ Large croppers and browsers } \\
\hline & Acanthuridae & 0.6 & 1.8 & 7.9 & $\cdots$ & $O>M=I$ & $\cdots$ \\
\hline & Siganidae & 3.1 & 2.9 & 0.2 & $\cdots$ & $\mathrm{I}=\mathrm{M}>\mathrm{O}$ & ns \\
\hline
\end{tabular}

Table 6. Distribution of major taxa of planktivores, expressed as total weight (kg) in all collections, across inshore, mid-shelf and outer shelf reefs. Symbols as Tables 1 and 4

\begin{tabular}{|c|c|c|c|c|c|c|c|}
\hline \multirow[t]{2}{*}{ Guild } & \multirow[t]{2}{*}{ Taxon } & \multirow[t]{2}{*}{ Inshore } & \multirow[t]{2}{*}{ Mid-shelf } & \multirow[t]{2}{*}{ Outer shelf } & \multicolumn{2}{|r|}{ Reefs } & \multirow{2}{*}{$\begin{array}{c}\text { Depth } \\
F^{\prime}\end{array}$} \\
\hline & & & & & $\mathrm{F}$ & SNK & \\
\hline \multicolumn{8}{|c|}{ Zooplanktivores } \\
\hline & Holocentridae & 3.3 & 7.4 & 12.3 & ns & - & ns \\
\hline & Pomacentridae & $(0.4)$ & $(32.9)$ & $(11.3)$ & & & \\
\hline & Chromis spp. (excl. C. atripectoralis) & 0.0 & 3.0 & 8.5 & $\cdots$ & $O>M>I$ & ns \\
\hline & C. atripectoralis & 0.0 & 24.3 & 2.7 & $\cdots$ & $M>O>I$ & ns \\
\hline & Neopomacentrus azysron & 0.4 & 5.6 & 0.1 & $\cdots$ & $M>I>0$ & ns \\
\hline & Miscellaneous & 0.1 & 2.0 & 2.3 & & & \\
\hline \multicolumn{8}{|c|}{ Omnivorous planktivores } \\
\hline & Abudefduf spp. & 0.6 & 3.3 & 0.0 & \pm & - & - \\
\hline & Acanthochromis polyacanthus & 10.3 & 5.7 & 2.1 & $\cdots$ & $\mathrm{I}=\mathrm{M}>\mathrm{O}$ & ns \\
\hline & Amblyglyphidodon spp. & 0.2 & 11.5 & 0.5 & $\cdots$ & $M>I=0$ & ns \\
\hline & Neopomacentrus anabatoides & 8.5 & 0.0 & 0.0 & $\ddagger$ & - & - \\
\hline & Pomacentrus spp. & 1.8 & 9.0 & 3.5 & $\cdots$ & $M>I=O$ & ns \\
\hline & Miscellaneous & 0.0 & 0.4 & 0.8 & & & \\
\hline \multicolumn{8}{|c|}{ Gelatinous planktivores } \\
\hline & Caesio caerulaureus & 0.0 & 7.7 & 6.3 & $\cdots$ & $M>I=0$ & ns \\
\hline & C. erythrogaster & 37.6 & 109.9 & 0.1 & $\mp$ & - & - \\
\hline & Pterocaesio diagramma & 0.0 & 62.9 & 37.0 & $\cdots$ & $O=M>I$ & ns \\
\hline & Miscellaneous & 0.0 & 0.0 & 5.1 & & & \\
\hline
\end{tabular}

differ significantly across the shelf (Table 6). Among the omnivorous planktivores, Pomacentrus spp. (10 g) and Amblyglyphidodon spp. (20 g) in particular, are far more abundant on the mid-shelf than elsewhere; Acanthochromis polyacanthus $(20 \mathrm{~g})$ was abundant inshore as well as on the mid-shelf and Neopomacentrus anabatoides ( $3 \mathrm{~g}$ ) is present only on inshore reefs where it is extremely abundant (Table 6).
The relative total weight of omnivorous and zooplanktivorous fish changes from the outer shelf to inshore reefs (parenthetic numbers in Table 4). The relative importance of omnivorous planktivores decreases consistently with increasing distance from the mainland and the abundance and relative importance of zooplanktivores is extremely low inshore. The genus Chromis which comprised 65 and $43 \%$ of zoo- 
planktivores by weight on the mid-shelf and outer shelf was totally absent from the inshore reef and the total weight of zooplanktivores on the inshore reef was an order of magnitude lower than that at the other reefs (Table 4).

\section{Invertebrate Feeders}

The total weight of non-planktivorous feeders on invertebrates varied less among reefs than that of algal grazers or planktivores, perhaps in part reflecting the greater artificiality of this trophic category. Within this category, fish feeding on motile invertebrates were

Table 7. Distribution of families of motile invertebrate feeders, expressed as total wet weight $(\mathrm{kg})$ in all collections, across inshore, mid-shelf and outer shelf reefs

\begin{tabular}{|lccc|}
\hline \multicolumn{1}{|c}{ Family } & Inshore & $\begin{array}{c}\text { Mid- } \\
\text { shelf }\end{array}$ & $\begin{array}{c}\text { Outer } \\
\text { shelf }\end{array}$ \\
\hline Apogonidae & 2.2 & 1.3 & 0.2 \\
Balistidae & 0.0 & 1.1 & 2.5 \\
Chaetodontidae & 0.9 & 0.6 & 2.9 \\
Holocentridae & 1.4 & 1.0 & 7.6 \\
Labridae & 8.2 & 9.8 & 15.5 \\
Lethrindae & 1.5 & 4.2 & 3.0 \\
Lutjanidae & 5.5 & 1.1 & 6.2 \\
Nemipteridae & 1.4 & 3.0 & 8.5 \\
Plectorhynchidae & 6.2 & 6.0 & 3.0 \\
Other & 1.7 & 0.7 & 0.8 \\
$\quad$ Total weight & 29.0 & 28.8 & 50.2 \\
\hline
\end{tabular}

Table 8. Distribution of major piscivorous taxa, expressed as total weight $(\mathrm{kg})$ in all collections, across inshore, mid-shelf and outer shelf reefs. " species regarded as facultative piscivores, the rest as confirmed piscivores

\begin{tabular}{|lrrc|}
\hline \multicolumn{1}{|c}{ Taxon } & Inshore & $\begin{array}{c}\text { Mid- } \\
\text { shelf }\end{array}$ & $\begin{array}{c}\text { Outer } \\
\text { shelf }\end{array}$ \\
\hline Apogonidae & 0.3 & 0.2 & 0.0 \\
Aulostomidae & 0.0 & 0.5 & 0.0 \\
Belonidae & 0.0 & 3.0 & 0.0 \\
Carangidae & 0.0 & 1.6 & 0.0 \\
Sphyraenidae & 0.0 & 1.1 & 0.0 \\
Synodontidae & 0.0 & 0.1 & 0.0 \\
Serranidae & 15.2 & 14.6 & 4.7 \\
Cephalopholis argus & 0.0 & 1.1 & 3.0 \\
- C. miniatus & 4.2 & 5.4 & 0.0 \\
- C. pachycentron & 5.1 & 0.0 & 0.0 \\
- C. urodelus & 0.0 & 0.0 & 1.4 \\
Epinephalus summana & 2.1 & 1.0 & 0.0 \\
Plectropomus leopardus & 0.0 & 2.2 & 0.0 \\
P. maculatus & 2.4 & 0.0 & 0.0 \\
Miscellaneous & 1.4 & 4.9 & 0.3 \\
Total weight & 15.5 & 21.2 & 4.7 \\
\hline
\end{tabular}

clearly the dominant guild on all reefs, comprising $71 \%$ by weight of the trophic category and including $45 \%$ of all species collected (Table 3 ). Prey items as diverse as crustaceans, polychaetes and molluscs are taken by this 'guild'. A more detailed analysis may reveal some differentiation within the group across the shelf but this is beyond the scope of the present study. The patchy distribution of many species and the relatively large weight of a few individuals (including plectorhynchids, lutjanids, Cheilinus undulatus and nemipterids) mean that only a limited interpretation of the distribution of taxa (Table 7) can be made. The Labridae are the most abundant family within this group on all reefs and comprise 42 of the 138 species which are distributed among 23 families. Among the feeders on motile invertebrates, 3 families showed significantly different $(\mathrm{P}<0.01)$ distributions among the reefs. The biomass of apogonids ( 3 to $60 \mathrm{~g} \mathrm{fish}^{-1}$ ) was significantly greater inshore and on the mid-shelf than on the outer shelf, that of balistids (60 to $450 \mathrm{~g}$ ) was significantly greater on the mid-and outer shelf than inshore. The total weight of holocentrids (50 to $200 \mathrm{~g})$ was significantly higher on the outer shelf than elsewhere (SNK comparisons, as elsewhere).

The relatively small biomass of coral feeders, sessile omnivores and feeders on sessile invertebrates (Table 4) greatly limits comparisons among reefs. There was no significant difference in total weight of any of these guilds between reefs.

\section{Piscivores}

The total weight of piscivores was considerably less than that of the other trophic categories. The collections suggest that piscivores are less abundant on the outer shelf than elsewhere (but see Discussion). Serranids were the major piscivores on all reefs in terms of both biomass and numbers. Other taxa appear to be well represented only on the mid-shelf (Table 8). Among the serranids, Cephalopholis spp. were the most abundant species on all reefs. On the inshore reef the small species $(40 \mathrm{~g})$ Cephalopholis pachycentron was extremely numerous (113 collected) followed by the larger $(175 \mathrm{~g}) \mathrm{C}$. miniatus (20 fish collected). C. miniatus was also numerous on the mid-shelf (38 fish collected). On the outer shelf, $C$. urodelus (95 g) and $C$. argus $(600 \mathrm{~g})$ were the most abundant piscivores. While the numbers of the latter 2 species collected were relatively small (15 and 5 individuals, respectively), extensive observations on a number of outer shelf reefs in the Great Barrier Reef and of several reefs in the Coral Sea indicate that $C$. urodelus, $C$. argus and Lutjanus bohar (see Discussion) are generally the most abundant piscivores in these habitats. 


\section{Trophic Structure}

Analysis of trophic structure by weight indicates differences in trophic structure among the reefs (Fig. 5). Planktivores were the major trophic category on all reefs due largely to a huge contribution from the caesionids species. Caesionids species apart, inverte-

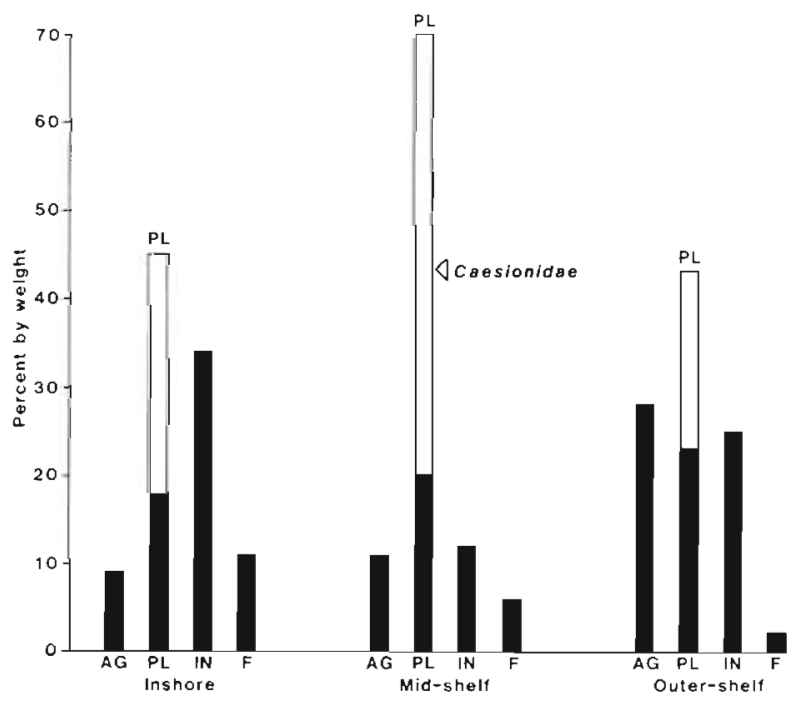

Fig. 5. Trophic structure of communities on each reef expressed as proportion of total weight of fish collected on each reef brate feeders formed the largest trophic component inshore, planktivores the largest on the mid-shelf and on the outer shelf the biomass of algal grazers, planktivores and invertebrate feeders did not differ greatly from each other.

Trophic structure by number of species gives a very different picture, with the invertebrate feeders (primarily the feeders on motile invertebrates) dominating on all reefs (Table 9). By the same measure, the largest differences among the reefs are the relatively fewer species of planktivore inshore and fewer species of piscivore on the outer shelf.

Planktivores comprised the majority of individuals on all reefs (Table 9). This dominance is apparently less on the outer shelf ( 67 percent of the total cf. 88 and $90 \%$ ) where algal grazers comprise a significant proportion of total numbers (22\%).

\section{DISCUSSION}

\section{General}

The total standing crop of fishes on the inshore reef (920 kg ha-1), estimated from the mean of all ten stations, is in the mid-range of values recorded for other reef fish communities (175 to $1950 \mathrm{~kg} \mathrm{ha}^{-1}$ Goldman and Talbot, 1976). The standing crop on the outer shelf

Table 9. Distribution of number of individuals and number of species (pooled for all stations) by trophic category and guild across inshore, mid-shelf and outer shelf reefs. Percent of total for each reef in parentheses

\begin{tabular}{|c|c|c|c|c|c|c|}
\hline \multirow{3}{*}{$\begin{array}{c}\begin{array}{c}\text { Trophic categories } \\
\text { Guilds }\end{array} \\
\text { Algal Grazers }\end{array}$} & \multicolumn{3}{|c|}{ Individuals } & \multicolumn{3}{|c|}{ Species } \\
\hline & Inshore & Mid-shelf & \multirow{2}{*}{$\begin{array}{l}\text { Outer shelf } \\
1044 \quad(22)\end{array}$} & \multirow{2}{*}{$\begin{array}{l}\text { Inshore } \\
13(12)\end{array}$} & \multirow{2}{*}{$\begin{array}{l}\text { Mid-shelf } \\
30(15)\end{array}$} & \multirow{2}{*}{$\begin{array}{l}\text { Outer shelf } \\
28(17)\end{array}$} \\
\hline & $413 \quad$ (4) & $427 \quad$ (3) & & & & \\
\hline Suckers & 0 & 37 & 152 & 0 & 1 & 3 \\
\hline Small croppers & 385 & 284 & 758 & 6 & 15 & 12 \\
\hline Large croppers & 18 & 32 & 54 & 4 & 4 & 5 \\
\hline Scrapers & 10 & 74 & 80 & 3 & 10 & 8 \\
\hline Planktivores & $9640(88)$ & $11482(90)$ & $3230(67)$ & $14(13)$ & $47 \quad(23)$ & 41 (25) \\
\hline Zooplankton & 187 & 7052 & 1708 & 5 & 24 & 27 \\
\hline Omnivorous & 8178 & 3332 & 457 & 8 & 20 & 9 \\
\hline Gelatinous & 1275 & 1098 & 820 & 1 & 3 & 4 \\
\hline Algal & - & - & 245 & & & 1 \\
\hline Invert Feeders & $732 \quad(7)$ & $737 \quad(6)$ & $534(11)$ & 69 (63) & $103(51)$ & 89 (55) \\
\hline Motile & 460 & 431 & 350 & 56 & 77 & 64 \\
\hline Sessile & 26 & 15 & 46 & 3 & 5 & 7 \\
\hline Sessile omniv. & 15 & 32 & 22 & 4 & 10 & 9 \\
\hline Coral & 231 & 259 & 116 & 6 & 11 & 9 \\
\hline Piscivores & $188 \quad(2)$ & $84 \quad$ (1) & $26 \quad$ (1) & $14(13)$ & 21 (10) & $5 \quad(3)$ \\
\hline Confirmed & 17 & 23 & 5 & 2 & 8 & 1 \\
\hline Facultative & 171 & 61 & 21 & 12 & 13 & 4 \\
\hline Total & 10973 & 12730 & 4834 & 110 & 201 & 163 \\
\hline
\end{tabular}


$\left(1560 \mathrm{~kg} \mathrm{ha}^{-1}\right)$ is towards the high end of recorded values and that on the mid-shelf ( $\left.2373 \mathrm{~kg} \mathrm{ha}^{-1}\right)$ is the highest yet recorded for a coral reef.

The relative rarity of the majority of species at given sites and the very small size of most fishes that we observed on each reef are consistent with the observations of Goldman (1973) and Russell et al. (unpubl. MS), at One Tree (Lat. $23^{\circ} 30^{\prime}$ ) and Yonge (Lat. $14^{\circ} 35^{\prime}$ ) reefs on the Great Barrier Reef.

\section{Distribution of Species}

Virtually all species are unevenly distributed among inshore, mid-shelf and outer shelf reefs. The high proportion of species collected by us at only 1 of the 3 reefs (Fig. 3) may, however, overestimate the actual proportion of species that are restricted to only one kind of reef. A disproportionate number of the restricted species were rare $(82 \%$ comprised less than 10 individuals in the entire collection) compared to the number of cosmopolitan species that were rare (only $23 \%$ classified rare), suggesting that the high proportion of restricted species may partly be an artifact of sampling relatively few individuals from a community comprising many rare species $(2 \times 2$ Chisquare constingency test, $P<0.005)$. Thus, larger samples of the same communities would probably decrease the proportion of species 'restricted' to only one reef. It should also be stressed that a species present in the study area on one reef but not in another may be present on the latter reef in a different habitat.

\section{Species Diversity}

The species richness (number of species per unit area) of the inshore reef was significantly less than the other reefs (Table 1). This difference may be due to the different physical and biological environment in inshore waters, to a reduced supply of larvae, to the relatively small size of the reef or to a lack of habitat diversity (no reef crest, flat or slope deeper than $13 \mathrm{~m}$ ) or a combination of these factors. The most likely explanation for the higher species richness on the midshelf than the outer shelf is a greater habitat heterogeneity in the former area.

The increase in the evenness or equitability component of species diversity with distance from the mainland is of considerable interest. Such gradients of evenness have been attributed to increasing environmental stability (Tramer, 1969), to an increase in the relative importance of competition in determining community structure (Pulliam et al., 1968) and to changes in the degree of spatial heterogeneity or habitat patchiness (Rotenberry, 1978). Determination of which of these factors, if any, cause the observed pattern will require detailed studies of the factors determining the abundances of individual species within the community.

\section{Distribution of Trophic Groups}

The clearest changes in the abundance of different trophic categories across the shelf are the high biomass of planktivores on the mid-shelf and low biomass of algal grazers on the inshore reefs. Changes in the availability of food across the shelf are a likely explanation of these patterns but we presently have little information on the availability of plankton and algae across the shelf. Andrews and Gentien (1982) have suggested that a greater biomass of zooplankton around the mid-shelf reefs than the outer shelf reefs, consistent with the observed distribution of planktivores, might be expected due to the upwelling of nutrient rich water on the edge of the continental shelf followed by wind driven passage of this water across the shelf. Plankton communities near an upwelling tend to be characterised by a high biomass of phytoand bacterio-plankton (Vinogradov et al., 1973, cited in Parsons et al., 1977). Ageing of the water, which is equivalent to moving away from the centre of the upwelling (from the outer shelf to the mid-shelf in the present case), is accompanied by a shift in dominant biomass to herbivorous, and later carnivorous, zooplankton.

This upwelled water would not, however, intrude as far as the inshore reefs. Andrews and Gentien (1982) have divided the study area into 2 different longitudinal regions, one in which water is mostly unstratified vertically (the lagoon) and seasonally influenced by terrestrial run-off (Wolanski and Jones, 1981) and one which is mostly stratified vertically (the Great Barrier Reef) and influenced by the Coral Sea. The outer shelf and mid-shelf reefs represent the outer and inner limits of the Great Barrier Reef region and the inshore reefs are within the lagoon waters. (This is a useful regional description but it would be very difficult to apply in the Northern and Southern regions - sensu Maxwell, 1968 - of the G.B.R.). While there may or may not be differences in algal productivity between the inshore reefs and other reefs, the algal communities inshore differ greatly from those elsewhere, perhaps explaining the very low densities of most algal grazers inshore. On the mid-shelf and outer shelf the algae primarily eaten by fish form a fine algal turf (the EAC of Hatcher, 1982a). These turfs do not occur in great abundance inshore and are replaced by a large standing crop of macroalgae, primarily Sargassum and Turbinaria, which is 
apparently not palatable to the fishes. Ikeda (pers. comm.) has indicated that there is an order of magnitude increase in the biomass of zooplankton from the open waters of the mid-shelf to those inshore. The abundance of planktivores is clearly not correlated with this change but we do not know how accurately these open water densities compare to densities of plankton in close proximity to the reefs or what proportion is likely to be palatable to reef fishes.

The collections suggest that piscivores may be less abundant on the outer shelf than elsewhere but this may in part be a sampling artifact. The density of Cephalopholis spp. is probably less on the outer shelf than elsewhere but Lutjanus bohar, a voracious piscivore, is much more abundant on the reefs of the outer shelf than elsewhere. This species is considerably larger than the Cephalopholis spp. and the home ranges of individuals are much larger than the areas of our collections. It is thus not surprising that none were collected and quite possible that $L$. bohar is a major predator in the outer shelf community. It should also be noted that the potentially piscivorous moray eels (family Muraenidae) which do not possess a swim bladder were not collected by our technique. Their distribution across the shelf is not known.

\section{Trophic Structure}

The trophic structure of reef fish communities changes among reef zones (Goldman and Talbot, 1976) as well as between reefs at the same latitude (present study). In addition, the relative role of the fish versus other biotic components of the reef's trophic structure may vary greatly among reefs (Goldman and Talbot, 1976). Clearly, one must be careful in making general statements concerning the trophic structure of coral reef fishes (cf. Bakus, 1969) and in interpreting such statements.

\section{Generality of the Results}

Our results refer specifically to 1 habitat, the rich reef slope, on 1 inshore, 1 mid-shelf and 1 outer shelf reef. We expect that variability in structure within zones and among reefs at similar locations on the continental shelf will be small relative to be differences among inshore, mid-shelf and outer shelf habitats (see Williams, 1982). Studies in progress indicate that major cross-shelf variation in at least species composition and relative abundance also occurs among fish communities associated with other reef habitats (Williams, Hatcher and Doherty, in prep.; Russ, pers. comm.).

\section{Factors Causing and Maintaining Differences in Community Structure}

Most species of fish on coral reefs have a pelagic larval phase (Sale, 1980). The proximal factors determining the observed distributions of fish could act at any, or all, of 3 stages in the life history of the fish. The patterns could be the result of:

(1) Differential availability of larvae across the shelf;

(2) patterns of settlement and habitat selection by postlarvae; or

(3) differential survivorship after settlement.

The simplest possible explanation for maintenance of the patterns of distribution is that as a result of mainstream water movements or the behaviour of larvae, larvae are unevenly distributed across the continental shelf and so inshore, mid-shelf and outer shelf reefs have different pools of larvae. Mainstream currents in the area, and presumably any large scale dispersal, are predominantly longshore as required by this hypothesis (Williams, Wolanski and Andrews, in prep.). Whether those currents, perhaps in combination with larval behaviour, are sufficient to cause different pools of larvae across the shelf that correlate with differences among communities on the reefs remains to be tested.

At the time of settlement, the transition from a pelagic existence to a reef-associated one, fishes are remarkably adept at selecting the habitat in which to settle (e.g. Williams, 1980; Williams and Sale, in prep.). At least 3 environmental factors likely to influence habitat selection differ markedly among our 3 study sites (Done, 1982): water quality, including sediment load and composition and abundance of the plankton; benthic communities, comprising primarily corals and algae; and species composition and relative abundances of fishes.

Interspecific interactions among fishes could cause the observed distribution by influencing patterns of settlement or survivorship after settlement. Anderson et al. (1981) observed change in the structure of assemblages of chaetodontid fishes along a cross-shelf transect in the Lizard Island region $400 \mathrm{~km}$ to the north of the present study. They concluded on the basis of patterns of distribution of species and guilds within the assemblage that inter-specific competition for food and/or space was a major factor determining the crossshelf distributions (but see Sale and Williams, 1982 for a different interpretation of the data).

Physical factors acting directly or indirectly on food supply, such as those influencing the upwelling and transport of nutrient rich water suggested by Andrews and Gentien (1982), may also be important in determining and maintaining the trophic structure of fish communities on coral reefs. The relationship between 
such forces, food supply and fish communities has received little attention in the past and clearly warrants more detailed study. In the present case efforts are required to determine whether the upwelled water, which initially forms a relatively narrow bottom layer of cool water in the area between the reefs, does cause the hypothetical change in food supply and that this food becomes available to the reef communities.

We conclude with a word of caution to those attempting to compare community structure among such distant sites as along latitudinal gradients (e.g. Talbot, 1982) or among oceans (e.g. Bohnsack and Talbot, 1980; Gladfelter et al., 1980). Our studies have revealed major changes in community structure in the same reef habitat at a single latitude within one reef system. Valid comparisons among widely separated regions can only be made after data is available on the range of variation within each region.

Acknowledgements. This study would not have been possible without extensive field assistance. John Hardman's efforts were particularly appreciated. We also thank N. Bellamy, J. H. Choat, D. Diener, B. Hatcher, H. Larson, R. Martin, L. Quetin, R. Ross and H. Sweatman. Bruce Hatcher provided valuable assistance with computer programming. G. Russ, R. Black and P. Doherty reviewed drafts of the manuscript, and made several helpful suggestions. Much of the inspiration for this study was provided by earlier, largely unpublished work of G. R. V. Anderson, B. Goldman, B. C. Russell and F. H. Talbot.

\section{LITERATURE CITED}

Anderson, G. R. V., Ehrlich, A. H., Ehrlich, P. R., Roughgarden, J. D., Russell, B. C., Talbot, F. H. (1981). The community structure of coral reef fishes. Am. Nat. 117: 476-495

Andrews, J. C., Gentien, P. (1982). Upwelling as a source of nutrients for the Great Barrier Reef ecosystems: a solution to Darwin's question? Mar. Ecol. Prog. Ser. 8: 257-269

Bakus, G. J. (1969). Energetics and feeding in shallow marine waters. Int. Rev, gen. exp. Zool. 4: 275-369

Bohnsack, J. A., Talbot, F. H. (1980). Species packing by reef fishes on Australian and Caribbean reefs: an experimental approach. Bull. mar. Sci. 30: 710-723

Box, G. E. P. (1953). Non-normality and tests on variances. Biometrika 40: 318-335

Done, T. J. (1982). Patterns in the distribution of coral communities across the central Great Barrier Reef. Coral Reefs, in press

Gladfelter, W. B., Ogden, J. G., Gladfelter, E. H. (1980). Similarity and diversity among coral reef fish communities; a comparison between tropical western Atlantic (Virgin Islands) and tropical central Pacific (Marshall Islands) patch reefs. Ecology 61: 1156-1168
Goldman, B. (1973). Aspects of the ecology of the coral reef fishes of One Tree Island. Ph. D. thesis, Macquarie University, Sydney, Australia

Goldman, B, Talbot, F. H. (1976). Aspects of the ecology of coral reef fishes. In: Jones, O. A., Endean, R. (eds.) Biology and geology of coral reefs, Vol. IV, Biology 2. Academic Press, New York, pp. 125-154

Harmelin-Vivien, M. L. (1981). Trophic relationships of reef fishes in Tuléar (Madagascar). Oceanol. Acta 4:365-374

Hatcher, B. G. (1982a). Grazing in coral reef ecosystems. In: Barnes, D. J. (ed.) Perspectives on coral reefs. Townsville, Australian Institute of Marine Science, in press

Hatcher, B. G. (1982b). The interaction between grazing organisms and the epilithic algal community of a coral reef: a quantitative assessment. Proc. 4 th int. Symp. Coral Reefs, in press

Mann, K. H. (1965). Energy transformation by a population of fish in the River Thames. J. Anim. Ecol. 34: 253-275

Maxwell, W. G. H. (1968). Atlas of the Great Barrier Reef, Elsevier Scientific Publishing Company, Amsterdam

Parsons, T R., Takahashi, M., Hargrave,B. (1977). Biological oceanographic process, 2nd ed., Pergamon Press, Oxford

Peet, R. K. (1974). The measurement of species diversity. Ann. Rev. Ecol. Syst. 5: 285-307

Pulliam, H. R., Odum, E. P., Barrett, G. W. (1968). Equitability and resource limitation. Ecology 49: 772-774

Root, R. B. (1967). The niche exploitation pattern of the bluegrey gnatcatcher. Ecol. Monogr. 37: 317-350

Rotenberry, J. T. (1978). Components of avian diversity along a multifactorial climatic gradient. Ecology 59: 693-699

Russell, B. C., Talbot, F. H., Anderson, G. R. V., Goldman, B. (1978). Methods of collection and sampling of coral reef fishes. In: Stoddart, D. R., Johannes, R. E. (eds.) Coral reefs: research methods. UNESCO, Paris, pp. 329-345

Sale, P. F. (1980). The ecology of fishes on coral reefs. Oceanogr. Mar. Biol. Ann. Rev. 18: 367-421

Sale, P. F., Williams, D, McB. (1982). Community structure of coral reef fishes: are the patterns more than those expected by chance? Am. Nat. 120: 121-127

Talbot, F. H. (1982). Fish species diversity on reef slopes from four coral reef areas in the west Pacific. Paper presented at 4th int. Symp. Coral Reefs, Manila

Tramer, E. J. (1969). Bird species diversity: components of Shannon's formula. Ecology 50: 927-929

Underwood, A. J. (1981). Techniques of analysis of variance in experimental marine biology and ecology. Oceanogr. Mar. Biol. Ann. Rev. 19: 513-605

Whittaker, R. H. (1969). Evolution of diversity in plant communities. Brookhaven Symp. Biol. 22: 178-196

Williams, D. McB. (1980). Dynamics of the pomacentrid community on small patch reefs in One Tree Lagoon (Great Barrier Reef). Bull. mar. Sci. 30: 159-170

Williams, D. McB. (1982). Patterns in the distribution of fish communities across the central Great Barrier Reef. Coral Reefs 1: 35-43

Wolanski, E., Jones, M. (1981). Physical properties of Great Barrier Reef Lagoon waters near Townsville. I. Effects of Burdekin River Floods. Aust. J. mar Freshwat. Res. 32: 305-319 